\title{
Collaborative Consumption as a Source of Market Disruption
}

\author{
Petteri Repo, Päivi Timonen \\ University of Helsinki, Helsinki, Finland
}

\begin{abstract}
The concept of collaborative consumption has been developed in consumer studies to define new consumption opportunities which are facilitated by information systems. Accordingly, novel services such as the ridesharing service Uber, for transport, and the hospitality-brokering service Airbnb, for accommodation, successfully employ collaboration in consumption and provide consumers with novel types of access to services. Yet while the identification of this new characteristic of consumption is of great merit, less attention has been paid in consumer studies to how it challenges existing market arrangements. It is against this background that this article examines collaborative consumption as a source of market disruption. The article applies the concept to the empirical case of a pilot scheme in collaborative public transport (Kutsuplus), which essentially consisted of a taxi-like bus service in Helsinki, Finland. It argues that collaborative consumption may tend to contribute premium rather than standard quality in public services, which is apt to disrupt both public and private service markets. The analysis further affirms that the concept of collaborative consumption is well suited to the assessment of novel services and their disruptive characteristics.
\end{abstract}

Keywords: collaborative consumption, consumer studies, market disruption, public and private services, transport

\section{Introduction}

Novel consumption arrangements are emerging in the digital world, and the concept of collaborative consumption provides a rationale for their successes (Belk, 2014; Barnes \& Mattson, 2016; see also Bason, 2010). Rapidly growing markets in shared transport provide an example of how collaborative consumption may change the dynamics of service offerings and disrupt existing market arrangements in collective transport (Giesler, Veresiu, \& Siebert, 2015; Bardhi \& Eckhardt, 2012). Collaborative consumption then transforms markets through consumer use of digital resources and the pooling of activities (Labrecque, vor dem Esche, Mathwick, Novak, \& Hofacker, 2013).

This article addresses the possible benefits and challenges of applying the concept of collaborative consumption in the realm of potentially disruptive services. It first examines how collaborative consumption may contribute to new service offerings and combines this with insights into disruption from innovation studies. The outcomes from an empirical case study of the medium-scale deployment of a novel, collaborative kind of public transport in Finland, Kutsuplus, are used to examine how the concept of collaborative consumption helps

Petteri Repo, Ph.D. (Econ.), adjunct professor (Docent), researcher director, Centre for Consumer Society Research, Faculty of Social Sciences, University of Helsinki, Helsinki, Finland.

Päivi Timonen, Ph.D. (Econ.), adjunct professor (Docent), researcher director, Centre for Consumer Society Research, Faculty of Social Sciences, University of Helsinki, Helsinki, Finland.

Correspondence concerning this article should be addressed to Petteri Repo, University of Helsinki, Unioninkatu 40 C, FI-00014, Finland. 
to assess the reception of novel services that challenge existing market arrangements. The final section of this article discusses how the concept of collaborative consumption can be further applied to review the disruptive features of novel services.

\section{Collaborative Consumption as a Source of Disruptive Innovation for Public Services}

Scholars recognize that involving consumers in innovation creates opportunities for ideological, economic, and institutional change in service offerings (Bason, 2010; Christensen, Grossman, \& Hwang, 2008; Parker \& Gallagher, 2007; Timonen \& Repo, 2014; Fledderus, Brandsen, \& Honingh, 2015). This is particularly interesting in the realm of public service systems that do not inherently seek change, as they are established parts of stable socio-technological regimes (see Geels, 2004; Geels \& Kemp, 2012). In such cases, novel interlinkages between the technologies of supply, user preferences and relevant policies are then required in order to facilitate consumer involvement. A shift from the traditional economy of owning toward an online economy that encompasses elements of collaboration and sharing indeed provides opportunities for new service offerings. The most prominent examples of such sharing services function in the private sector, with Uber providing transport and Airbnb accommodation, with both relying on the efficient sharing of resources.

Consumer studies have, however, recognized that there is more to collaborative consumption than simply sharing existing resources. Belk (2014) goes as far as to declare that access to services rather than ownership of goods constitutes the identity of a consumer. In this context, he defines collaborative consumption as the coordination of the acquisition and distribution of a resource for a fee or other compensation (Belk, 2014, p. 1597). In their study on car sharing, Bardhi and Eckhardt (2012) demonstrate that this collaborative, access-based consumption comprises six dimensions: (1) temporality, (2) anonymity, (3) market mediation, (4) consumer involvement, (5) type of accessed object, and (6) political consumerism. In this article, collaborative consumption is approached from the perspective of developing a novel kind of transport service that is collaboratively constructed and is provided for a fee. The present article incorporates the six dimensions identified by Bardhi and Eckhardt (2012) into the analysis and employs them in the public transport case study.

Public service offerings are particularly interesting from the perspective of collaborative consumption, as they concern the collective rather than individual use and funding of services. While the digitalization of services has accentuated the opportunities for new service offerings, innovation in the public sector has typically sought productivity and efficiency gains over transformation or disruption (Bason, 2010). Hence, introducing collaborative elements such as citizen involvement and market mediation may lead to disruptive service features (Christensen, Baumann, Ruggles, \& Sadtler, 2006), which in turn prompt changes not only in the consumption but also in the production of the public-sector services in question.

In principle, public services are accessible to all consumers, although there may be restrictions, and policies may support positive discrimination, i.e., provide selected citizens with special service offerings. Variety in supply and service differentiation, nevertheless, poses challenges for the public sector, which has difficulties in meeting highly individualized demand (Bason, 2010). The supply of public services is, furthermore, founded on the idea that democratic decision making determines citizen access and the rationale of access to services, for instance through fixed schedules and limited availability. Further challenges are posed by common premises for the public supply of services, such as a not-for-profit ethos and inclusiveness. Accordingly, the public sector has been a conservative innovator, and the specifics of public sector innovation have become internationally recognized only after the turn of the millennium (Windrum, 2008). 
For public services, collaborative consumption possesses particular disruptive potential, and as consumers increasingly use similar criteria to evaluate public services and private services (see Wensley \& Moore, 2011; Fledderus et al., 2015), customers are becoming an integral part of the provision of services (Prahalad \& Ramaswamy, 2004; Bardhi \& Eckhardt, 2012; Hyysalo, Repo, Timonen, Hakkarainen, \& Heiskanen, 2016), and consumerism challenges how public service offerings are decided on and regulated (Denhardt \& Denhardt, 2015; Baldwin, Cave, \& Lodge, 2012). The transformation of public service offerings is also facilitated by the emergence of disruptive technologies in information networks, smart technologies and automatization, which are also prompting institutional changes (Christensen et al., 2008; Repo, Timonen, \& Zilliacus, 2009). Such disruption both throws into relief and complements the ideas of organizations which rely on routines (Vala, Pereira, \& Caetano, 2017) or need to listen closely to their stakeholders (Alapo, 2018) and which might thus be overly conservative in situations where the respective field is experiencing radical change (Fliegstein, 2013; Repo, Hyvonen, Pantzar, \& Timonen, 2006).

Consumption-related disruptive technologies promise both more efficiently provided public service offerings and the emergence of new competences that can be used in their provision. These disruptive technologies and institutional developments facilitate the transformation of public service offerings in the direction of increasing automation, self-service and peer-to-peer supply, all of which develop the activities of consumers in the direction of collaborative consumption. Such development is disruptive in that it blurs the roles of producers and consumers; thus it has been described with terms such as prosumers (Toffler, 1980) and lead users (Hippel, 2005). Terms such as co-creation (Prahalad \& Ramaswamy, 2004) and co-production (Bovaird, 2007), in turn, define activities that embrace consumers in production and development processes, both reflecting features attributed to collaborative consumption.

Being disruptive, collaborative consumption accordingly possesses the potential for developing public service offerings - not only through its increased use in the production of these services but also through their redefinition. Collaborative consumption therefore provides an opportunity to adapt offerings to consumer practices, thus ensuring better responsiveness to current and evolving demand (Schatzki, 2010; Shove, Pantzar, $\&$ Watson, 2012). It also complements attempts to extend political modes of consumerism beyond private markets (see Micheletti, 2003; Graziano \& Forno, 2012), as the collaborative disruptive technologies in question have often been first adopted in private consumer markets. In particular, new information systems in mobility, health, interaction, and customership in general are currently challenging public service offerings.

When analyzing mobility as a public service, account must therefore be taken of both consumer benefits and the process through which expectations for public services have been determined (Alford, 2016). At the same time, disruptive innovations are apt to face resistance from established players on the market, as highlighted in the Kutsuplus case presented in the upcoming section of this article.

\section{Case of Collaborative Consumption in Public Transport}

The Kutsuplus service pilot for public transport in the Helsinki Metropolitan Area in Finland is used as a case study for investigating the disruptive features of collaborative consumption in the field of public transport. Helsinki Region Transport (HRT) acted as the service developer of the concept (see Goodman, Korsunova, \& Halme, 2017), which from the onset was likely considerable disruption in public bus and private taxi markets in the Helsinki Metropolitan Area as well as within the operator itself. Passenger use of the Kutsuplus pilot constituted collaborative consumption due to the specific temporality of service creation and provision, 
anonymity between users, mediation taking place in the public online market, consumer determination of schedules and routes and political consumerism of a public service (Bardhi \& Echardt, 2012). Furthermore, it involved coordination or acquisition of a service for a fee (Belk, 2014).

The Kutsuplus pilot has received international attention, in particular in the domain of transport. Weckström, Mladenović, Ullah, Nelson, Givoni, and Bussman (2018), for instance, review Kutsuplus in a survey-based user study in an attempt to draw lessons for the further development of flexible micro-transit. In turn, Jokinen, Sihvola, and Mladenovic (2017) adopt similar development perspectives when assessing the service features of Kutsuplus and accompanying policy processes. The Kutsuplus pilot has indeed been seen to represent an experiment with or an attempt to develop new kinds of transitional frameworks and policies in transportation, urban settings and sustainability (Mäkinen, Kivimaa, \& Helminen, 2015; Cohen \& Muñoz, 2016; see Lane, 2017 on implementation gaps and game theory). Moreover, Kutsuplus can be seen to constitute a concrete case of Mobility as a Service (MaaS), which, for its part, attempts to match customer needs to an evolving service supply (Hensher, 2017).

While this earlier research considers stakeholders in the field, it nevertheless neither focuses on the collaborative-consumption character of the Kutsuplus transport concept nor explicitly considers how this disrupts existing market arrangements. In the following sections, the Kutsuplus pilot is presented and evaluated against the notion of collaborative consumption. The case description is based on public documents relating to the Kutsuplus pilot, media sources, and studies commissioned and published by Helsinki Region Transport.

\section{The Kutsuplus Pilot Service}

A key feature of the Kutsuplus public transport pilot was that the schedules and routes of the 15 Kutsuplus buses were dynamically determined as passengers placed and paid for their orders using a system separate from the regular bus card system. Accordingly, Kutsuplus had no predefined schedules or routes, and its buses arrived to collect passengers at any bus stop in the pilot area within an average of nine minutes after placing the order. In essence, the Kutsuplus concept was positioned between taxi and bus services.

"Kutsu" translates as "call", "invite", and "summon" in the Finnish language, and it thus highlights the consumers' active role in triggering the service. The service concept was developed in a university research project that began in 2007. The testing phase of the concept proceeded in October 2012, and the service was opened for public use in a pilot in April 2013. The Kutsuplus concept quickly attracted considerable attention, and it was awarded a prize for being the year's best act to benefit customers in Finland in 2014 (CXPA Finland 2014). Furthermore, the growth in rides was rapid, even though Kutsuplus remained a niche in the public transport system.

Ticket revenues cover only part of the operation costs of public transport in Finland. Accordingly, Kutsuplus was initially heavily supported to the sum of $40 €$ per ride, corresponding to an over 80 percent subsidy. Nevertheless, this halved to $20 €$ and was expected to reach $15 €$ by the end of the pilot (HSL, 2015b; Laita, 2014). Thus, it was calculated to reach a lower level of subsidy than that of other public transport (HSL, 2014c; Laita, 2014). In comparison, at the time, the rate of public subsidies for Helsinki Region Transport was 49 percent, which matched public support for bus transport in other large urban areas in Finland (49\%) but was higher than the subsidy provided for taxi traffic (41\%, consisting mainly of reimbursements for travel expenses) (Finnish Transport Agency 2017). Consumer satisfaction indicators for Kutsuplus reached high levels, with an 
overall rating of 4.6 out of 5 (HSL, 2014c). Rides grew by 59 percent during the second year of operation to 9,200 per month, and targets for ticket revenues were expected to be met.

The Kutsuplus pilot service was, nevertheless, terminated in December 2015, in spite of high levels of consumer satisfaction, the growing popularity and full functionality of the service both in terms of bus traffic and its accompanying online ordering and purchasing system, and the prospects of it matching or exceeding the economic viability of regular bus traffic in the near future. Revised plans focused on the transfer of the Kutsuplus system to taxi-like market players, who were to begin operations in 2017-2018; however, this never occurred.

\section{Evaluation of the Kutsuplus Pilot}

The evaluation of the Kutsuplus pilot follows the overall criteria for collaborative consumption as set by Belk (2014) and analytically captured in Bardhi and Eckhardt's dimensions of access (2012). Accordingly, the following factors are examined: (1) the concept of the Kutsuplus service (temporality, anonymity, mediation, consumer involvement, functional type of service, coordination, acquisition, functional type of service), (2) willingness to pay (fee), and (3) the scale of use of the service as it relates to access. In addition, consumer satisfaction is also considered, as it relates to the motivation to use the service (Belk, 2014; Bardhi \& Eckhardt, 2012). Finally, the disruptive potential of innovation in public service offerings is assessed, as this relates to the dimension of political consumerism (Bardhi \& Eckhardt, 2012) and is connected to the discontinuation of service development and operation. The results of this evaluation are summarized in Table 1.

Table 1 demonstrates that users of the Kutsuplus service were willing to pay a premium for the service, as 66.5 percent of Kutsuplus passengers were willing to pay 4.00-5.99€ and 13.9 percent to pay 6.00-7.99€, while the price of a regular single ticket was 3.00€, and HRT offered discounted prices for multiple tickets and season tickets.

The Kutsuplus service experienced rapid growth (59\% during the last pilot year). Nevertheless, access to the service remained limited, as it required active enrolment on the service through its own payment system, which implied separate customership. Activeness was also expected from the users in the online ordering of rides. In comparison, regular bus traffic provided a much larger magnitude of scheduled and routed rides (15 million vs. 9,200 monthly; HSL, 2014a) and relied on regular payment systems, including cash.

High scores for consumer satisfaction were nonetheless achieved, with an overall score of $4.6 / 5$ and a ride specific score of 4.84/5, which both exceeded the overall score of 4.24/5 for regular buses (HSL, 2014b; 2014c). The speed and fluidity of transport was also highly valued, at 4.66/5. By contrast, users were less satisfied with the network of stops (4.15/5), although they were able use any bus stop in the area of operation. This further indicates that Kutsuplus was considered a premium service which should have provided an even better reach for passengers, perhaps door to door, and routing based on addresses rather than stops.

Collaborative consumption in the form of Kutsuplus contributed both to internal and external disruption of activities and markets. Internally, it challenged the HRT strategy built on predesigned trunk lines with high capacity and feeder traffic (HSL, 2016). The financial viability of Kutsuplus was also questioned. Accordingly, five of the seven cities backing the Kutsuplus pilot opted for termination while two remained neutral (HSL, 2015a). Termination of the Kutsuplus pilot was in line with a strategy focused on a large-scale, non-premium, and non-exclusive public service. 
Table 1

Features of the Kutsuplus Service and Assessment of Access and Disruption

\begin{tabular}{|c|c|c|}
\hline Feature of service and its use & Outcomes & Relation to access and disruption \\
\hline Concept & $\begin{array}{l}\text { Consumers integral part of the dynamic formation } \\
\text { of routes and schedules of buses }\end{array}$ & $\begin{array}{l}\text { Access for some: Those actively using } \\
\text { the service }\end{array}$ \\
\hline $\begin{array}{l}\text { Willingness to pay (for } 5 \text { kilometer } \\
\text { ride, } N=245 \text { ) }\end{array}$ & $\begin{array}{l}6-7.99 €: 13.9 \% \\
4-5.99 €: 66.5 \% \\
\text { less than } 4 €: 20.8 \%\end{array}$ & $\begin{array}{l}\text { Access for some: Acceptance for } \\
\text { premium price (regular price for } \\
\text { one-way ticket was } 3.00 € \text { in } 2015 \text { ) }\end{array}$ \\
\hline Scale of use & Growth $59 \%$ in last year, to 9,200 monthly rides & $\begin{array}{l}\text { Access for some: Small share of the } 15 \\
\text { million monthly HSL bus rides }\end{array}$ \\
\hline Consumer satisfaction, $\mathrm{N}=250$ & & \multirow{5}{*}{$\begin{array}{l}\text { - Access contributes to premium quality } \\
\text { High level of consumer satisfaction } \\
\text {-(average overall score for regular } \\
\text { transport system } 4.24 \text { ) }\end{array}$} \\
\hline Overall grade of this ride & $4.84 / 5$ & \\
\hline $\begin{array}{l}\text { Kutsuplus serves with an appropriate } \\
\text { network of stops }\end{array}$ & $4.15 / 5$ & \\
\hline Transport is quick and fluent & $4.66 / 5$ & \\
\hline $\begin{array}{l}\text { Overall grade of the Kutsuplus } \\
\text { service }\end{array}$ & $4.6 / 5$ & \\
\hline \multicolumn{2}{|l|}{ Disruption of innovation } & \multirow[b]{2}{*}{$\begin{array}{l}\text { Disruption: Challenges strategy which } \\
\text { focuses on large-scale non-premium } \\
\text { and non-exclusive public service }\end{array}$} \\
\hline Internal: Challenges strategy & $\begin{array}{l}\text { - HRT strategy focuses on trunk lines and feeder } \\
\text { traffic } \\
\text { - Financial viability questioned } \\
\text { - } 5 \text { of } 7 \text { participating cities responded critically to } \\
\text { the idea of continuing the pilot, } 2 \text { were neutral }\end{array}$ & \\
\hline External: Disrupts markets & $\begin{array}{l}\text { - Challenges established market for taxi services } \\
\text { - Challenges public purchases of supported-ride } \\
\text { services for citizens (in particular concerning } \\
\text { taxis) }\end{array}$ & $\begin{array}{l}\text { Disruption: Challenges established } \\
\text { markets, in particular the market for } \\
\text { taxis and the accompanying public } \\
\text { purchases }\end{array}$ \\
\hline
\end{tabular}

Sources: HSL (2014a; 2014b; 2014c; 2015a; 2015b; 2016).

Being positioned between taxis and buses, the Kutsuplus service also disrupted the established market for taxi services. The taxi sector expressed discontent with a public competitor and was concerned that public purchases would be shifted from taxi rides to bus rides.

In sum, evaluating the Kutsuplus case through the concepts of collaborative consumption and disruption sheds light on why an arguably popular and innovative public service was discontinued. Even the rather positive outlook for Kutsuplus, which provided a service in a novel way, was insufficient to secure its longevity. The conceptual dimensions of access also provide an explanation for why satisfaction and growing popularity amongst collaborating consumers was apt to lead to a premium rather than standard service. This caused internal and external disruption in related markets, which eventually contributed to the termination of the pilot and to attempts to transfer the service to market actors (HSL, 2015b).

\section{Discussion and Conclusions}

Collaborative consumption and access to online services have been identified as offering increasing opportunities for consumers (Belk, 2014; Bardhi \& Eckhardt, 2012; Barnes \& Mattson, 2016). Car sharing services provide frequently quoted examples of how collaborative consumption has shifted from a physical to a partly online world. Indeed, the combination of online and physical offerings also appears to provide novel service opportunities through collaborative consumption for the public sector. 
This article has examined how the concept of collaborative consumption can be applied to an innovative case of public transport. The digitalization of services and constraints in public spending provide the impetus to develop such public service innovations. Similarly, collaborative consumption may itself encourage the public sector to be more innovative in the development of its offerings (see Bason, 2010; Fledderus et al., 2015) or at least seek areas in which such innovativeness would be welcomed (Bovaird, 2007). Nonetheless, innovativeness may also cause disruption (Christensen et al., 2006), as the Kutsuplus case study shows. Kutsuplus was novel in that it allowed for collaborative consumption to contribute to the dynamic evolution of public bus routes and schedules.

Applying the concept of collaborative consumption can also help explain the possible disruptive features of redesigned public services. In the case of Kutsuplus, consideration of the dimensions of access helps to contrast hopeful outlooks and experiences against prevalent market arrangements. The case suggests that if collaborative consumption leads to public services of premium rather than standard quality and challenges the dominant logic of the provision of public services, the disruptive potential of service innovations means they may be challenging to realize. Indeed, the evaluation of the Kutsuplus pilot ends by indicating the possibility of utilizing the concept of collaborative consumption not only as a force for change but also as a concept for analyzing the limits of variety and differentiation in public service innovations. It would then appear a good idea to consider the political aspects of consumerism and the disruptive nature of innovations when introducing collaborative consumption to public services.

While the case of Kutsuplus can be considered a success story from the perspective of collaborative consumption and the adoption of novel services, the service was nevertheless terminated due to the market disruption it caused. The story did not, however, end there, as Ajelo, the company developing and operating the information system for the transport service, was acquired by the American startup Split, which further developed and piloted the system in Washington D.C. Later, the German automaker Volkswagen backed the startup MOIA in its acquisition of the company, which launched its "shuttle by demand" service in Hanover, Germany in 2018, indicating how potentially disruptive services may need to travel across industries to find their niches. In the Helsinki region, MaaS Global has launched its Whim service, which combines public and taxi rides and, in particular, connects the newly opened stops of the metropolitan subway with people's homes.

In the case of the Kutsuplus pilot, the risk for disruption was explicit, as the pilot did not conform to the strategy of Helsinki Region Transport (see Jokinen et al., 2017) and was challenged by other market players. Enthusiasm over collaborative consumption may at first overshadow public concerns and lead to unforeseen issues when deploying new services that rely on collaborative consumption. Against this background, the article highlights the applicability of the concept of access not only for identifying collaborative services but also for developing such services in the domain of public offerings.

\section{References}

Alapo, R. (2018). Influences of contextual, cultural factors and stakeholders on system design and management analysis in organizations. Management Studies, 6(2), 108-112.

Alford, J. (2016). Co-production, interdependence and publicness: Extending public service-logic. Public Management Review, 18(5), 673-691.

Barnes, S. J., \& Mattsson, J. (2016). Understanding current and future issues in collaborative consumption: A four-stage Delphi study. Technological Forecasting and Social Change, 104, 200-211.

Bason, C. (2010). Leading public sector innovation. Co-creating for a better society. Bristol: The Policy Press. 
Baldwin, R., Cave, M., \& Lodge, M. (2012). Understanding regulation: Theory, strategy, and practice (2nd ed.). Oxford: Oxford University Press.

Bardhi, F., \& Eckhardt, G. M. (2012). Access-based consumption: The case of car sharing. Journal of Consumer Research, 39(4), $881-898$.

Belk, R. (2014). You are what you can access: Sharing and collaborative consumption online. Journal of Business Research, 67(8), $1595-1600$.

Bovaird, T. (2007). Beyond engagement and participation: User and community coproduction of public services. Public Administration Review, 67(5), 846-860.

Christensen, C. M., Grossman, J. H., \& Hwang, J. (2008). The innovator's prescription: A disruptive solution for health care. New York: McGraw Hill.

Christensen, C. M., Baumann, H., Ruggles, R., \& Sadtler, T. M. (2006). Disruptive innovation for social change? Harvard Business Review, 84(12), 94-103.

Cohen, B., \& Munoz, P. (2016). Sharing cities and sustainable consumption and production: Towards an integrated framework. Journal of Cleaner Production, 134, 87-97.

CXPA Finland. (2014). Vuoden parhaaksi asiakasteoksi valittiin HSL: n Kutsuplus (Kutsuplus by Helsinki region transport was selected as best customer act of the year). Retrieved 20.8.2018 from http://www.cxpa.fi/news/vuoden-parhaaksi-asiakasteoksi-valittiin-hsln-Kutsuplus/

Denhardt, J. V., \& Denhardt, R. B. (2015). The new public service: Serving, not steering (4th ed.). New York: M. E. Sharpe.

Finnish Transport Agency. (2017). Public transport performance statistics 2015. Statistics of the Finnish Transport Agency 7/2017. Retrieved 20.8.2018 from https://julkaisut.liikennevirasto.fi/pdf8/1ti_2017-07_public_transport_web.pdf

Fledderus, J., Brandsen, T., \& Honingh, M. E. (2015). User co-production of public service delivery: An uncertainty approach. Public Policy and Administration, 30(2), 145-164.

Fligstein, N. (2013). Understanding stability and change in fields. Research in Organizational Behavior, 33, 39-51.

Geels, F. W. (2004). From sectoral systems of innovation to socio-technical systems. Insights about dynamics and change from sociology and institutional theory. Research Policy, 33(6-7), 897-920.

Geels, F. W., \& Kemp, R. (2012). The multi-level perspective as a new perspective for studying socio-technical transitions. In F. W. Geels, R. Kemp, G. Dudley, and G. Lyons (Eds.), Automobility in transition. A socio-technical analysis of sustainable transport (pp. 49-79). London: Routledge.

Giesler, M., Veresiu, E., \& Siebert, A. (2015). Designing a sharing economy through the process of market empathization. In K. Diehl and C. Yoon (Eds.), NA-Advances in Consumer Research, 43, 152-156. Duluth, MN: Association for Consumer Research.

Goodman, J., Korsunova, A., \& Halme, M. (2017). Our collaborative future: Activities and roles of stakeholders in sustainability-oriented innovation. Business Strategy and the Environment, 26(6), 731-753.

Graziano, P. R., \& Forno, F. (2012). Political consumerism and new forms of political participation: The Gruppi di Acquisto Solidale in Italy. The Annals of the American Academy of Political and Social Science, 644(1), 121-133.

Hensher, D. A. (2017). Future bus transport contracts under a mobility as a service (MaaS) regime in the digital age: Are they likely to change? Transportation Research Part A: Policy and Practice, 98(Part A), 86-96.

Hippel, E. (2005). Democratizing innovation. Cambridge: The MIT Press.

HSL. (2014a). Vuosikertomus 2014 (Annual report 2014). Helsinki Region Transport. Retrieved 20.8.2018 from https://www.hsl.fi/sites/default/files/uploads/hsl_vuosikertomus_fi_2014_nettiin.pdf

HSL. (2014b). Asiakastyytyväisyys liikennemuodoittain (Consumer satisfaction according to mode of transport). Helsinki Region Transport. Retrieved 20.8.2018 from https://hsl.louhin.com/asty/tables/?_tiny=a2b189mjhruy3lj0

HSL. (2014c). Kari Rissanen: Kutsuplus.fi, 10.6.2014 (Presentation by Kari Rissanen on Kutsuplus.fi). Helsinki Region Transport. Retrieved 20.8.2018 from https://dev.hel.fi/paatokset/media/att/79/79fbb31192b713ab089a323eb7718123eff117b3.pdf

HSL. (2015a). HSL: N alustava toiminta-ja taloussuunnitelma 2016-2018. Yhteenveto kuntien lausunnoista. HSL: N hallituksen iltakoulu 16.9.2015 (HRT's preliminary operational and financial plan for 2016-2018. Summary of municipalities' statements. The meeting of the HRT board. 16.9.2015). Helsinki Region Transport. Retrieved 20.18.2018 from http://docplayer.fi/32759539-Hsl-n-alustava-toiminta-ja-taloussuunnitelma-yhteenveto-kuntien-lausunnoista.html

HSL. (2015b). Hallitus. Pöytäkirja 17.11.2015 Pykälä 152 (Board. Minutes 17.11.2015 Section 152). Helsinki Region Transport. Retrieved 9.1.2018 from http://hs101.hosting.documenta.fi/kokous/2015404-2.HTM

HSL. (2016). HSL's strategy. Helsinki Region Transport. Retrieved 20.8.2018 from https://www.hsl.fi/en/strategy 
Hyysalo, S., Repo, P., Timonen, P., Hakkarainen, L., \& Heiskanen, E. (2016). Diversity and change of user driven innovation modes in companies. International Journal of Innovation Management, 20(2), 1650023.

Jokinen, J. P., Sihvola, T., \& Mladenovic, M. N. (2017). Policy lessons from the flexible transport service pilot Kutsuplus in the Helsinki Capital Region. Transport Policy. doi:10.1016/j.tranpol.2017.12.004

Labrecque, L. I., vor dem Esche, J., Mathwick, C., Novak, T. P., \& Hofacker, C. F. (2013). Consumer power: Evolution in the digital age. Journal of Interactive Marketing, 27(4), 257-269.

Laita, S. (2014). Hurjasti suosiotaan kasvattanut Kutsuplus on kallis veronmaksajalle - tuki 39.80 euroa matkalta (Kutsuplus increased its popularity hugely yet is expensive for tax payers - subsidy 39.80 euros per ride). Retrieved 20.8.2018 from http://www.hs.fi/kaupunki/a1416980622079

Lane, J. E. (2017). Could it happen: Global warming leads to the extinction of mankind? Management Studies, 5(6), 545-554.

Mark, G. (2018). A socio-technical perspective on the design of IT architectures: The lowlands lens. Management Studies, 6(3), 177-187.

Micheletti, M. (2003). Political virtue and shopping: Individuals, consumerism, and collective action. New York: Palgrave Macmillan.

Mäkinen, K., Kivimaa, P., \& Helminen, V. (2015). Path creation for urban mobility transitions: Linking aspects of urban form to transport policy analysis. Management of Environmental Quality: An International Journal, 26(4), 485-504.

Parker, S., \& Gallagher, N. (Eds.). (2007). The collaborative state: How working together can transform public services. London: Demos.

Prahalad, C. K., \& Ramaswamy, V. (2004). Co-creating unique value with customers. Strategy and Leadership, 32(3), 4-9.

Repo, P., Timonen, P., \& Zilliacus, K. (2009). Alternative regulatory cases challenging consumer policy. Journal of Consumer Policy, 32(3), 289-301.

Repo, P., Hyvonen, K., Pantzar, M., \& Timonen, P. (2006). Inventing use for a novel mobile service. International Journal of Technology and Human Interaction, 2(2), 49-64.

Schatzki, T. R. (2010). The timespace of human activity: On performance, society, and history as indeterminate teleological events. Lanham: Lexington.

Shove, E., Pantzar, M., \& Watson, M. (2012). The dynamics of social practice. London: Sage.

Timonen, P., \& Repo, P. (Eds.). (2014). Käyttäjälähtöinen innovaatiopolitiikka neljässä maassa (User driven innovation policy in four countries). TEM-raportteja 3/2014. Helsinki: Työ- ja elinkeinoministeriö.

Toffler, A. (1980). The third wave. New York: Bantam Books.

Vala, L., Pereira, R., \& Caetano, I. (2017). Innovation management processes and routines for business success and value creation. Management Studies, 5(5), 471-481.

Weckström, C., Mladenović, M. N., Ullah, W., Nelson, J. D., Givoni, M., \& Bussman, S. (2018). User perspectives on emerging mobility services: Ex post analysis of Kutsuplus pilot. Research in transportation business \& management. doi:10.1016/j.rtbm.2018.06.003

Wensley, R., \& Moore, M. H. (2011). Choice and marketing in public management: The creation of public value? In J. Benington and M. H. Moore (Eds.), Public value. Theory and practice (pp. 127-143). New York: Palgrave Macmillan.

Windrum, P. (2008). Innovation and entrepreneurship in public services. In P. Windrum and P. Koch (Eds.), Innovation in public sector services (pp. 3-20). Cheltenham: Edward Elgar. 